\title{
Memórias e entrevistas de um professor primário para um inquérito folclórico argentino
}

Vitor Hugo Silva Néia ${ }^{1}$

\begin{abstract}
RESUMO: Em 1921, o Conselho Nacional de Educação, responsável pelas políticas educacionais na Argentina, autorizou a realização de um inquérito para coletar, nas imediações das escolas sob sua jurisdição, manifestações folclóricas consideradas tradicionais. Essa iniciativa estava intimamente ligada ao pensamento nacionalista que passava a ver os milhões de imigrantes que chegavam ao país desde o século XIX como fatores de risco para a identidade nacional. O exercício resultou em mais de $88 \mathrm{mil}$ fólios, enviados, sobretudo, por docentes e diretores. Este artigo analisará a contribuição de Augusto Valle, professor primário de um estabelecimento escolar do Território Nacional do Río Negro. Mais do que a compilação de elementos relacionados ao folclore, essa documentação dialoga com as dinâmicas históricas de seu tempo e oferece registros biográficos de seu autor e dos personagens entrevistados por ele, ora se aproximando, ora contrariando os sentidos originalmente pretendidos pelos autores do inquérito.
\end{abstract}

Palavras-chave: inquérito folclórico; História da Argentina; narrativa autobiográfica.

\section{Memories and interviews by a primary school teacher in an Argentine folklore inquiry}

\begin{abstract}
In 1921, National Education Council, responsible for educational politics in Argentina, authorized realization of an inquiry to collect, around the schools under its jurisdiction, folklore manifestations considered traditional. This initiative was directly connected to nationalistic ideas, which regarded to millions of immigrants that have been arriving in the country since the 19th century as risk factors for national identity. These efforts resulted in more than 88,000 folios, sent, mainly, by teachers and principals. This article analyses contributions made by Augusto Valle, a primary teacher from a school at Río Negro National Territory. More than a compilation of elements related to folklore, these documents dialogue with historical dynamics and provide biographic registers from its author and people interviewed by him, sometimes bringing closer, sometimes disagreeing with original criteria sought by inquiry's creators.
\end{abstract}

Key words: folklore inquiry; Argentina History; autobiographical narrative.

Artigo recebido em: 18/12/2017

Artigo aprovado para publicação em: 09/05/2018

\footnotetext{
${ }^{1}$ Mestre em História Social pela Faculdade de Filosofia, Letras e Ciências Humanas da Universidade de São Paulo (FFLCH-USP), São Paulo, Brasil. Artigo resultante da pesquisa de Mestrado intitulada $A$ Encuesta del Folklore de 1921: cultura popular e nacionalismo argentino, defendida em 2016, sob a orientação da Prof. ${ }^{a}$ Dr. ${ }^{a}$ Gabriela Pellegrino Soares e em parte financiada pela CAPES. Contatos de email: vitor.neia@usp.br; vths@hotmail.com.
}

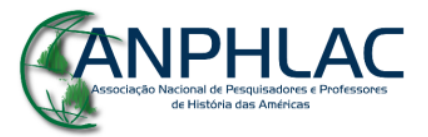

Revista Eletrônica da ANPHLAC, ISSN 1679-1061, №. 24, p. 72-100, Jan./Jun., 2018.

http://revista.anphlac.org.br 


\section{Introdução}

Desde o século XIX, os imigrantes europeus, sobretudo do Norte da Europa, eram vistos, por muitos políticos e pensadores relacionados ao projeto liberal para a nação argentina, como necessários para o desenvolvimento econômico e social do país. Contudo, diante da chegada de milhões de estrangeiros, a maioria deles vindos da Itália e da Espanha, as elites dominantes passaram a enxergá-los como fatores de instabilidade para a unidade e a identidade nacionais. Entre os diversos instrumentos utilizados para "argentinizá-los", de acordo com um conjunto de tradições e valores ideologicamente eleitos como autenticamente argentinos, a educação desempenhou papel fundamental, sobretudo a partir da gestão do médico positivista José María Ramos Mejía à frente do Conselho Nacional de Educação.

Além disso, um grupo de pensadores nacionalistas, muitos deles denominados pela historiografia como pertencentes à chamada Geração do Centenário da Independência, contribuiu na definição dos rumos das políticas educacionais na Argentina das primeiras décadas do século XX. Nesse contexto, foi autorizada a realização de um inquérito que deveria compilar o maior número possível de manifestações folclóricas consideradas tradicionais, em meio ao alegado risco de desaparecimento em virtude do fenômeno imigratório. Por meio da análise da documentação enviada por um professor do Território Nacional do Río Negro para a Encuesta Nacional del Folklore de 1921, este artigo propõe aproximar a temática das “escritas de si” a questões relacionadas às disputas em torno da consolidação simbólica da nação argentina, dialogando com dinâmicas históricas regionais e nacionais e com aspectos prosopográficos dos personagens que emergiram desses registros.

\section{Educação, imigração e nacionalismo}

A partir da segunda metade do século XIX, sobretudo com a ascensão do político liberal Bartolomé Mitre à Presidência da República Argentina em 1862 (BETHELL, 2009, p. 667), a educação passou a desempenhar um papel cada vez mais estratégico enquanto mecanismo pretensamente capaz de unificar um país marcado por décadas de conflitos que opuseram os chamados liberais aos federalistas, com seus respectivos projetos políticos de nação. Ao mesmo tempo, a questão educacional já

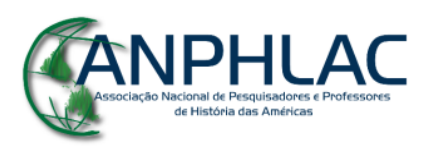

Revista Eletrônica da ANPHLAC, ISSN 1679-1061, №. 24, p. 72-100, Jan./Jun., 2018.

http://revista.anphlac.org.br 
vinha ocupando lugar de destaque entre os principais teóricos do liberalismo argentino, entre eles Juan Bautista Alberdi, mentor da Constituição de 1853 e um dos primeiros a defender a imigração europeia como solução para o desenvolvimento nacional (ALBERDI, 2011), e, especialmente, Domingo Faustino Sarmiento, considerado o “fundador do sistema escolar laico na Argentina" (CANCLINI, 1990, p. 154).

Sarmiento, que também governaria o país de 1868 a 1874, é o autor do clássico Facundo o civilización y barbarie en las pampas argentinas (1845), no qual expôs um projeto nacional assentado na dicotomia entre a civilização (associada às cidades e ao liberalismo) e a barbárie (simbolizada pela imagem do "deserto" do interior argentino, com suas planícies povoadas por indígenas, gaúchos e caudillos, vistos como emblemas do atraso daquele mundo rural). Não por acaso, durante sua Presidência, determinou a criação de fundos para o financiamento da educação pública nas províncias, por meio da Lei n. 463 de Subvenções Nacionais (PUIGGRÓS, 1991, p. 77).

Posteriormente, após passar pela Superintendência do recém-criado Conselho Nacional de Educação (CNE) em 1881 (CONSELHO NACIONAL DE EDUCAÇÃO, 1938), Sarmiento seria um dos principais colaboradores do texto da Lei n. ${ }^{\circ} 1.420$ de Educação Comum, promulgada em 1884. Ainda que, na prática, sua efetivação tenha encontrado obstáculos, sobretudo pela resistência dos governos provinciais, essa legislação foi responsável por consolidar um sistema educacional público, hierárquico, centralizado, laico, progressivo e que almejava ser utilitário e universal, mas "altamente discriminatório e que pretendeu homogeneizar as expressões da cultura popular" (PUIGGRÓS, 1991, p. 78-81), definindo um currículo escolar que refletia o modelo de modernização, civilização e progresso perseguido pelo Estado-nacional (ANAIS DA LEGISLAÇÃO ARGENTINA, 1884).

Esse sentido homogeneizador delineado para a educação pública seria reforçado diante do grande afluxo de imigrantes que chegaram ao país entre finais do século XIX e o início do século XX. Somente nas décadas de 1880 e 1890, mais de 1 milhão de pessoas emigraram para a Argentina, das quais 650 mil radicaram-se no país, cuja população totalizava cerca de 2 milhões de habitantes (ROMERO, 2012). Calcula-se que, de 1854 a 1914, mais de 4,6 milhões de estrangeiros tenham entrado em território argentino, maior contingente registrado em toda a América Latina (SECRETARIA DA AGRICULTURA, INDÚSTRIA E COMÉRCIO, 1950, p. 139-140). Ainda que muitos

\section{CANPHLAC}

Revista Eletrônica da ANPHLAC, ISSN 1679-1061, №. 24, p. 72-100, Jan./Jun., 2018.

http://revista.anphlac.org.br 
tenham se instalado nas cidades, especialmente em Buenos Aires, o campo também foi transformado pela chegada de imigrantes de nacionalidades tão diversas quanto espanhóis, italianos, ingleses, chilenos e russos, por exemplo (DEVOTO, 2000, p. 46).

Além de intensas mudanças demográficas e urbanísticas, esse fenômeno acirrou tensões políticas e conflitos sociais (SOARES, 2002, p. 24), levando à criação de novos dispositivos que visavam a "disciplinar" uma população cada vez mais heterogênea, entre os quais a Lei n. ${ }^{\circ} 4.144$ de 1902, que autorizou a deportação dos "perturbadores da ordem" sem julgamento prévio (CONGRESSO NACIONAL DA ARGENTINA, 1902). Já no âmbito da educação pública, foi sancionada, em 1905, a chamada Lei Láinez, que autorizou o governo federal a abrir escolas primárias nas províncias, sobretudo em áreas de baixa escolarização e com altos índices de analfabetismo (CONGRESSO NACIONAL DA ARGENTINA, 1905; PINEAU, 2007).

A partir de então, foram inaugurados centenas de estabelecimentos escolares sob a administração centralizada do CNE e, portanto, jurisdicionados pela Lei n. ${ }^{\circ} 1.420$ de Educação Comum de 1884. Isso permitiu não somente um maior controle dos currículos e das práticas educativas, mas também significou a predominância numérica das chamadas escolas nacionais sobre os estabelecimentos provinciais. Desse modo, o aprofundamento da presença institucional do Estado, especialmente nas regiões geograficamente mais afastadas dos grandes centros urbanos, tornou-se uma preocupação fundamental para os políticos e pensadores responsáveis pela condução do Ministério da Justiça e Instrução Pública.

Esse movimento acentuou-se à medida que o imigrante passou a ser visto não mais como uma solução para o país, mas agora como um fator de risco para a estabilidade social e a própria identidade nacional. Era preciso, pois, promover a criação de mecanismos capazes de "argentinizá-lo", e a escola seria o espaço privilegiado para esse projeto (ZAIDENWERG, 2016). Essas concepções ocuparam importância central entre os pensadores da chamada Geração do Centenário da Independência, comemorado em 1910. Nesse contexto:

Todos os conflitos sociais e políticos e todo o questionamento sobre os rumos da elite tradicional podiam ser atribuídos aos maus imigrantes, aos corpos estranhos [...] incapazes de valorizar o que o país lhes havia oferecido. [...] preocupava também a desintegração de uma identidade nacional que alguns remontavam à sociedade crioula, anterior à avalanche imigratória. [...] a

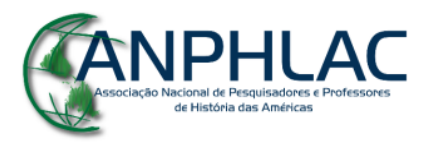

Revista Eletrônica da ANPHLAC, ISSN 1679-1061, №. 24, p. 72-100, Jan./Jun., 2018.

http://revista.anphlac.org.br 
maioria encontrou resposta em uma afirmação polêmica e retórica da nacionalidade: a solução era ressaltar a própria tradição crioula, argentinizar a massa estrangeira e, assim, discipliná-la. (ROMERO, 2012, E-book).

Essa doutrina foi denominada pela historiografia como nacionalista em virtude das preocupações compartilhadas sobre aquilo que deveria conformar a identidade e a nacionalidade argentinas, em especial por meio de atributos culturais associados a um conjunto de tradições eleitas como autenticamente nacionais, em oposição ao cosmopolitismo e à imigração (BEIRED, 1999). Muitos desses teóricos participavam dos debates acerca das políticas públicas educacionais, inclusive elaborando relatórios e pareceres ao Estado e ocupando funções e cargos no CNE. Manuel Gálvez, Ricardo Rojas e Leopoldo Lugones destacaram-se entre os principais representantes daquela Geração. Em linhas gerais, esse nacionalismo:

[...] era representado como um movimento e uma ideologia política de redenção nacional portadora dos valores essenciais da argentinidade. Estes deveriam ser buscados no passado, pois entendia-se que não havia pátria sem história, ciência moral e política que permitia o acesso à "consciência do ser nacional". (BEIRED, 1999, p. 226)

Mesmo que a ideia de uma pedagogia cívica para a escola pública argentina, inspirada no modelo francês, tenha sido debatida ainda no século XIX (DEVOTO, 2000, p. 41), esse impulso tomou vigor durante a gestão do médico e pensador positivista José María Ramos Mejía, que presidiu o Conselho Nacional de Educação de 1908 a 1913, período que coincidiu com as comemorações do Centenário da Independência. À frente do órgão, ele sistematizou e deu início à implantação de um projeto de educação patriótica, voltado à difusão dos valores nacionais por meio das escolas de todo o país.

Esse modelo "impregnaria tudo, desde os planos das diferentes disciplinas, a conduta no espaço escolar e fora dele, até os livros de texto ou manuais escolares" (ZAIDENWERG, 2013, p. 239). Os conteúdos das aulas foram orientados, quando possível, para exaltar os símbolos da nação (bandeira, hino, paisagens naturais, heróis fundadores, acontecimentos históricos, efemérides etc.), fosse nas disciplinas de História e Geografia, Leitura e Escrita e Instrução Moral e Cívica, fosse nos problemas de Aritmética ou por ocasião das festas comunitárias (ZAIDENWERG, 2013). Assim, o

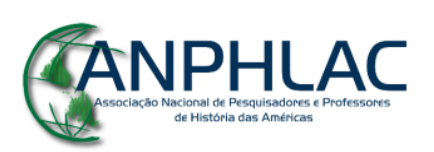

Revista Eletrônica da ANPHLAC, ISSN 1679-1061, №. 24, p. 72-100, Jan./Jun., 2018.

http://revista.anphlac.org.br 
objetivo dessas iniciativas, em consonância com o pensamento de Ramos Mejía, era "convergir todas as energias para a grandeza da pátria" e "impulsionar os povos pela senda da justiça, da glória e da liberdade” (RAMOS MEJÍA, 1909, p. 3).

Além da educação escolar e das celebrações cívicas, a valorização do folclore entendido como algo imutável e alheio às transformações sociais e históricas, posição predominante desde a construção desse conceito no século XIX, sobretudo pela Folklore Society (cf. NÉIA, 2017) - também aproximaria o Conselho Nacional de Educação do pensamento nacionalista de expoentes da Geração do Centenário, sobretudo Ricardo Rojas. Por conseguinte, estando vinculadas a elementos eleitos como representativos das tradições, dos costumes da terra e do passado, as manifestações folclóricas também foram reivindicadas como instâncias privilegiadas para o resgate das camadas profundas da identidade nacional e como meios de articulação da escola pública com o projeto de argentinização das massas. O auge desse movimento ocorreu em 1921, quando o CNE aprovou a realização do maior inquérito folclórico empreendido no país até então, a chamada Encuesta Nacional del Folklore.

\section{A Encuesta Nacional del Folklore de 1921 e o Território do Río Negro}

Em março de 1921, Juan Pedro Ramos, vogal e colaborador do Conselho Nacional de Educação e futuro dirigente do nacionalismo radicalizado dos anos 1930 (CATTARUZZA, 2012), propôs a realização de um inquérito para compilar as manifestações folclóricas dispersas pela Argentina, cujos métodos deveriam observar parâmetros previamente determinados pelo próprio CNE (CONSELHO NACIONAL DE EDUCAÇÃO; RAMOS, 1921). Para ele, era imprescindível que o Conselho empreendesse esses esforços o quanto antes, diante do risco de desaparecimento representado pela presença maciça dos imigrantes. Ao mesmo tempo, Ramos preocupou-se em valorizar a tradição hispânica, que era igualmente reivindicada por outros teóricos nacionalistas, reafirmando sentidos de permanência entre o passado espanhol e a cultura argentina. O projeto foi aprovado e executado no mesmo ano.

As orientações para a realização da Encuesta Nacional del Folklore, um dos nomes pelo qual ficou conhecido o inquérito, dispunham que os materiais deveriam ser coletados por toda a rede de escolas nacionais - incluindo aquelas criadas nas províncias em virtude da Lei Láinez de 1905 -, junto aos habitantes do entorno das

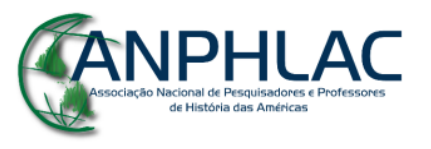

Revista Eletrônica da ANPHLAC, ISSN 1679-1061, №. 24, p. 72-100, Jan./Jun., 2018.

http://revista.anphlac.org.br 
unidades escolares. Elas abarcavam, em especial, os estabelecimentos das áreas rurais, entendidas pelo pensamento nacionalista como lugares privilegiados para a conservação da pureza das manifestações folclóricas, que ali estariam menos sujeitas às contaminações por fatores estrangeiros. No entanto, ainda que o campo, nas palavras de Juan P. Ramos, preservasse "intacta a nobre tradição do passado", a Encuesta também foi aplicada nos centros urbanos, incluindo a capital Buenos Aires.

O projeto reforçava a obrigatoriedade de que todos os registros compilados fossem nacionais, sem aportes decorrentes da imigração, com exceção das tradições espanholas. Também exigia que tudo fosse antigo, sem precisar a extensão temporal dessa noção, e preferencialmente coletado em língua castelhana, exceção feita aos idiomas indígenas, ainda que originalmente sem formas escritas.

Os professores foram escolhidos como os agentes primordiais para a condução do inquérito, devendo atuar como intermediários entre a cultura popular e o projeto do Estado-nacional. Por outro lado, as possibilidades cotidianas de recepção, apropriação e mediação converteram-nos em participantes ativos da Encuesta, os quais muitas vezes ignoraram ou subverteram as intenções hegemônicas do Conselho. As coletas foram incentivadas pela realização de um concurso, que premiaria com medalhas os docentes responsáveis pelos melhores trabalhos, segundo o julgamento de uma comissão. "A receptividade teria sido tanta que os professores solicitaram ao CNE a prorrogação de prazo, concedida afinal para 15 de novembro de 1921” (SOARES, 2015, p. 436).

Para sua execução, o Conselho publicou um livreto de instruções complementares, também vinculadas em seu informativo. As denominadas Instrucciones a los maestros foram elaboradas por Ramos em parceria com Pablo Córdoba, pró-secretário e colaborador do CNE. Dirigiam-se, especialmente, aos professores e visavam a apresentar a natureza do inquérito e a normatizar as categorias que direcionariam os esforços da coleta (RAMOS; CÓRDOBA, 1921, p. 3-25). Assim, propunham um esquema de classificação por grupos, cada qual com subdivisões internas, que serviria para orientar os trabalhos e facilitar o ordenamento do grande volume de informações colhidas: crenças e costumes; narrativas e refrãos; arte; costumes populares.

Essa divisão, nem sempre observada pelos professores e demais compiladores (como alguns diretores escolares, por exemplo), possuía imprecisões e chegou a ser

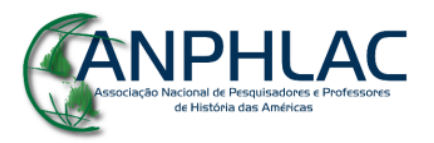

Revista Eletrônica da ANPHLAC, ISSN 1679-1061, №. 24, p. 72-100, Jan./Jun., 2018.

http://revista.anphlac.org.br 
criticada por um dos secretários do júri constituído para analisar os resultados do inquérito, Manuel de Ugarriza Aráoz (ESPOSITO; DI CROCE, 2013). Ainda assim, esse esforço de normatização foi importante para auxiliar os docentes que, pela primeira vez, realizavam uma tarefa do tipo e frente a uma rede que, em 1922, alcançaria 4.300 escolas de características bem diversas entre si, às quais acudiriam mais de meio milhão de alunos (CATTARUZZA, 2012). Além disso, as instruções determinavam que cada manifestação folclórica fosse remetida em folha separada, com cabeçalho contendo localidade, escola, nome do remetente, nome e idade do narrador, indicações de indivíduos que o conhecessem e quaisquer dados extras considerados pertinentes, apesar de muitos participantes terem ignorado essas orientações.

Ao final, o projeto conseguiu reunir 3.250 compiladores, que produziram 88.009 fólios de registros nos oito Territórios Nacionais e nas 14 províncias do país (FERREIRA, s/d). Dentro desse amplo universo documental, este artigo destacará a contribuição do professor Augusto Valle, docente primário da Escola Nacional n. ${ }^{0}$ 25, localizada em Lamarque, no Território Nacional do Río Negro. Como uma das regiões patagônicas de ocupação mais antiga, o Río Negro manteve-se como território povoado por indígenas e área politicamente autônoma dentro do Estado-nacional argentino até a década de 1880. Não obstante, sua história foi conformada por intensas interações entre os grupos e sujeitos que conviviam, combatiam ou se relacionavam naquela região.

Entre 1879 e 1885, durante as campanhas militares na Patagônia denominadas pela historiografia clássica como a Conquista do Deserto, foram incorporados pelas armas os futuros Territórios Nacionais do Río Negro (oficialmente constituído em 1884), Neuquén e Chubut. A chamada "solução final" para a questão indígena conformou na prática o discurso que via naquelas regiões um vasto, inóspito e atrasado deserto, entrave para o avanço do progresso e da civilização. Em relação aos impactos dessas campanhas sobre os nativos, uma diversidade de fatores atingiu "a vida comunitária, desarmando as estruturas políticas, sociais e econômicas, isolando seus membros entre si e dissolvendo rapidamente os valores tradicionais" (SARASOLA, 1992, p. 278).

Estima-se que foram feitas 2.196 vítimas fatais entre os indígenas ao longo desses confrontos militares. Outros milhares foram incapacitados, aprisionados, recrutados para trabalhos forçados ou morreram em razão de doenças e epidemias.

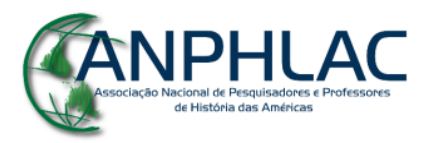

Revista Eletrônica da ANPHLAC, ISSN 1679-1061, №. 24, p. 72-100, Jan./Jun., 2018.

http://revista.anphlac.org.br 
Rapidamente, as políticas de fomento à imigração converteram-se em alternativas para invisibilizar a presença indígena e explorar os 60 milhões de hectares conquistados e distribuídos para os proprietários de terra (ZAIDENWERG, 2013, p. 99), marcando o início do controle do Estado-nacional sobre aqueles territórios.

Contudo, o Río Negro continuou a ser tratado como uma região marginalizada, de difícil ocupação prática e simbólica, a despeito das tentativas de institucionalização e consolidação administrativa empreendidas pelo governo central (FLORIA; NICOLETTI, 2001). Sobre ele, recairia fortemente o discurso de modernização do projeto liberal, que tinha na imagem do "deserto" um entrave ao desenvolvimento nacional, e, posteriormente, as intenções do nacionalismo emergente, em busca das pretensas tradições ameaçadas pelas tensões e pressões sociais da modernização.

No que se refere à educação, embora as escolas fossem diretamente subordinadas ao CNE, uma vez que se tratava de um Território Nacional, seu sistema educacional caracterizava-se por altos índices de evasão, infraestrutura precária, dificuldade em formar e atrair professores e pela concorrência da Congregação Salesiana, entre muitos outros desafios. A partir de 1908, os Territórios também atraíram a atenção do projeto patriótico de Ramos Mejía, especialmente preocupado com a argentinização daquelas populações que, além dos indígenas, eram igualmente distinguidas pela grande presença de imigrantes espanhóis, italianos, chilenos, russos e de diversas outras origens (GARCÍA; TEOBALDO, 1993; FLORIA; NICOLETTI, 2001). Nesse sentido, apesar do discurso nacionalista classificar as áreas rurais como ambientes menos sujeitos às influências estrangeiras, vale salientar que, em 1920, o Censo Geral dos Territórios Nacionais evidenciou que a proporção de imigrantes entre os 42.652 habitantes do Río Negro era de $31 \%$, além de $51 \%$ da população vivendo no campo (MOLDES; ENTRAIGAS, p. 2007, p. 16-22).

Assim, o conjunto documental enviado ao Conselho Nacional de Educação por Augusto Valle, um dos 20 professores do Río Negro que participaram da Encuesta del Folklore, foi considerado para análise neste artigo tanto pelas possibilidades de reflexão oferecidas pelas dinâmicas sociais e históricas desse Território Nacional quanto pelas particularidades da própria documentação, construída a partir de entrevistas com moradores locais, mas também com base nas memórias pessoais do docente, o que contrariou as orientações de coleta previamente feitas pelo CNE. Assim, esses registros

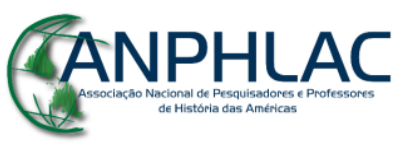

Revista Eletrônica da ANPHLAC, ISSN 1679-1061, №. 24, p. 72-100, Jan./Jun., 2018.

http://revista.anphlac.org.br 
incluem um relevante relato autobiográfico, atrelado a uma fonte bastante original, que são os inquéritos folclóricos idealizados pelo poder público, dialogando com seu tempo e coadunando-se com as "escritas de si" que compõem este dossiê.

\section{"Escrita de si”" em um inquérito folclórico: algumas questões metodológicas}

A historiadora Angela de Castro Gomes, ao prefaciar "Escrita de si, escrita da História", referência na historiografia brasileira a respeito da escrita de si, inclui os "diários, correspondência, biografias e autobiografias, independentemente de serem memórias ou entrevistas de história de vida" (GOMES, 2004, p. 7), entre os gêneros mais associados àquela temática. Mais ainda, a autora argumenta que, ao reconhecer o valor de todos os indivíduos, a sociedade moderna "abriu espaço para a legitimidade do desejo de registro da memória do homem 'anônimo' [...], cuja vida é composta por acontecimentos cotidianos, mas não menos fundamentais a partir da ótica da produção de si” (idem, p. 13). São documentos escritos e objetos pessoais (fotografias, postais etc.) que oferecem inúmeras possibilidades à pesquisa histórica.

A documentação analisada neste artigo pode inserir-se, grosso modo, na intersecção entre autobiografia e biografia, do professor-autor e dos personagens por ele entrevistados. Contudo, a particularidade dessa fonte reside no fato de que os relatos produzidos por Augusto Valle foram direcionados por sentidos que extrapolaram os registros biográficos tradicionais. Seu conteúdo estava orientado pelas diretrizes de agentes políticos, referendadas pelo Estado argentino em consonância com aspectos particulares à corrente nacionalista da qual a Encuesta Nacional del Folklore de 1921 foi uma das formas de expressão. Mais ainda, esses documentos seriam analisados por um júri e concorreriam a um prêmio, uma vez que a participação dos professores no inquérito foi estimulada pela realização de um concurso que elegeria a melhor produção ${ }^{2}$.

Além disso, os relatos compilados pelo professor do Río Negro fazem parte de um conjunto documental bastante específico, cuja estrutura cientificamente encaminhada deveria, em tese, afastá-lo da pessoalidade própria da escrita de si. Em

\footnotetext{
${ }^{2}$ Ainda que o inquérito tenha sido concluído em 1921, o resultado foi divulgado somente em 1945: Luís Gerónimo Lucero, professor da província de San Luís e compilador de 500 fólios, recebeu a medalha de ouro (MIGLIOZZI, 2005, p. 7-11).
}

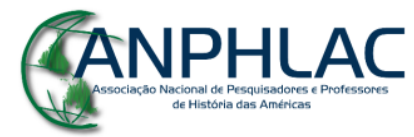

Revista Eletrônica da ANPHLAC, ISSN 1679-1061, №. 24, p. 72-100, Jan./Jun., 2018.

http://revista.anphlac.org.br 
espanhol, encuesta pode significar simplesmente uma indagação ou pesquisa ou, mais especificamente, "um conjunto de perguntas tipificadas dirigidas a uma amostra representativa de grupos sociais, para averiguar opiniões ou conhecer outras questões que os afetam”, segundo o Diccionario de la Real Academia Española. Do ponto de vista etimológico, originou-se do vocábulo francês enquete que, por sua vez, filia-se ao verbo latim inquaerere (inquerir, interrogar), relacionado à terminologia jurídica medieval inquesta (CENTRE NATIONAL DE RESSOURCES TEXTUELLE ET LEXICALES, 2016). Como método sociológico, o termo é geralmente traduzido como "entrevista" ou "questionário" no Brasil (BONI; QUARESMA, 2005, p. 68-80), conquanto a palavra "inquérito" seja utilizada em Portugal sob essa mesma acepção científica (LIMA, 2000).

Embora os inquéritos como procedimentos metodológicos tenham assumido distintos objetivos e hajam sido amplamente aprimorados, desenvolvidos e discutidos pelas Ciências Sociais ao longo dos séculos XIX e XX (BONI; QUARESMA, 2005, p. 69), há registros anteriores sobre o uso de questionários para coletar dados relacionados à cultura popular especificamente, como é o caso da Encuesta del Folklore. Entre os exemplos citados por Peter Burke, estão as questões elaboradas pelo abade Henri Grégoire em 1790 sobre costumes e dialetos franceses e aquelas feitas pela Sociedade das Terras Altas escocesa, em 1797, acerca da poesia gaélica (BURKE, 2010, p. 40).

Os primeiros inquéritos sociológicos cujas características básicas assemelhavamse às atuais foram aplicados por cientistas como Charles Booth e Karl Marx, a fim de "buscar informações sobre a situação socioeconômica das classes desfavorecidas" (MARTIN, 2011, p. 5). Outros exemplos menos estruturados remontam ao Antigo Regime, quando os reis franceses demandavam informações fiscais sobre a população e a economia dos departamentos e províncias, e o inquérito de um padre de Aragão sobre os milagres e os nomes das virgens de sua paróquia, no século XVI. A sistematização oficial desses procedimentos nos Oitocentos está relacionada à necessidade de controle do Estado-nacional sobre as normas e organizações burocráticas, correspondendo a seu processo de institucionalização, como ocorreu na Argentina (OSZLAK, 1982, p. 11). Daí a ênfase no mapeamento e tabulação de diversos aspectos da sociedade. Não por acaso, os primeiros censos nacionais são da mesma época.

\section{GANPHLAC}

Revista Eletrônica da ANPHLAC, ISSN 1679-1061, №. 24, p. 72-100, Jan./Jun., 2018.

http://revista.anphlac.org.br 
Por sua vez, ainda que subordinados ao Conselho Nacional de Educação e, portanto, a tentativas de dominação simbólica materializadas por relações assimétricas de poder, os professores souberam eleger estratégias de participação e mediação que lhe conferiram níveis de protagonismo que variaram de docente para docente. Muitos subverteram aqueles sentidos pré-determinados, fazendo escolhas e selecionando os materiais que lhes parecessem mais pertinentes, acrescentando opiniões e juízos, omitindo informações ou recuperando suas histórias de vida. Assim, puderam distanciar-se das proposições esquemáticas do inquérito, propondo novas abordagens e trilhando caminhos alternativos, como o uso de suas memórias.

Por conseguinte, ainda que diante das particularidades desse tipo de documentação, não se pode afastar a pertinência das discussões teórico-metodológicas que envolvem a temática da escrita de si em suas relações com os registros do professor Augusto Valle. Recuperando mais uma vez Angela Gomes, é importante considerar que nesse tipo de fonte "os indivíduos e os grupos evidenciam a relevância de dotar o mundo que os rodeia de significados especiais, relacionados com suas próprias vidas, [...] para serem dignas de ser lembradas" (GOMES, 2004, p. 11). À guisa de exemplo, o docente argentino chegou a incluir em seus relatos, como será visto mais adiante, a convivência com o indígena Ceferino Namuncurá, que seria beatificado pelo Vaticano em 2007 e que, mesmo quando o professor escrevia, já era cultuado como santo popular no país. Contudo, ainda que destacando essa amizade de infância, Valle não fez menção à santidade do antigo companheiro de colégio.

Outro aspecto relevante que perpassa a discussão acerca da escrita de si é a ideia de que "certas circunstâncias e momentos da história de vida de uma pessoa ou de um grupo estimulam essa prática", como os textos "que se voltam para o registro de fases específicas de uma vida, como viagens, estadas de estudo e trabalho, experiências de confrontos militares, prisão, enfim, um período percebido como excepcional" (GOMES, 2004, p. 19). Os relatos autobiográficos do docente argentino constroem-se, na sequência dos documentos analisados, justamente a partir de memórias sobre viagens de estudos na juventude e lembranças de sua vida escolar como aluno ou professor.

Em síntese, tendo em vista os argumentos aqui levantados, cabe destacar que as formas da escrita de si não podem ser consideradas como naturais ou espontâneas (GOMES, 2004, p. 22). Principalmente, como afirma Angela de Castro Gomes:

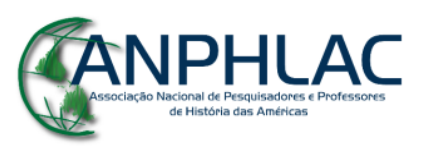

Revista Eletrônica da ANPHLAC, ISSN 1679-1061, №. 24, p. 72-100, Jan./Jun., 2018.

http://revista.anphlac.org.br 
Está descartada a priori qualquer possibilidade de se saber "o que realmente aconteceu" (a verdade dos fatos), pois não é essa a perspectiva do registro feito. O que passa a importar para o historiador é exatamente a ótica assumida pelo registro e como seu autor a expressa. Isto é, o documento não trata de "dizer o que houve", mas de dizer o que o autor diz que viu, sentiu e experimentou, retrospectivamente, em relação a um acontecimento. (GOMES, 2004, p. 15)

Também é importante considerar que os relatos do professor Augusto Valle se desenrolaram espacialmente em cidades localizadas às margens do rio Negro, acompanhando o trajeto das águas e de um ramal ferroviário adjacente e caracterizadas pela ocupação pioneira e o desenvolvimento econômico mais adiantado. Ademais, além de levar em conta as dinâmicas sócio-políticas do Território Nacional do Río Negro elucidadas no tópico anterior, a análise dos documentos compilados pelo docente irá recuperar aspectos históricos e prosopográficos das localidades e personagens mencionados em suas memórias ou pelas testemunhas por ele entrevistadas. Afinal, como ponderou Ariel de la Fuente - um dos primeiros historiadores a utilizar a Encuesta como fonte de pesquisa, concentrando-se na província argentina de La Rioja , os participantes do inquérito foram testemunhas oculares de fenômenos históricos (FUENTE, 2001).

As abordagens metodológicas propostas por Giovanni Levi (2000) em sua reconstituição da aldeia italiana de Santena no século XVII foram igualmente pertinentes para o breve exercício prosopográfico aplicado aos registros do docente, em especial no que refere à sua relação com o mundo rural. Guardadas as diferenças entre os distintos contextos e épocas aqui comparados, as comunidades camponesas, nas palavras de Levi, "não podem ser descritas através da imagem idílica de uma sociedade solidária e sem conflitos" (LEVI, 2000, p. 43). Essa constatação motivou o historiador italiano a se aprofundar em torno do que ele denominou de vicissitudes biográficas dos habitantes de Santena, a fim de compreender como eles participavam, interagiam e interferiam no dia a dia de uma comunidade permeada por relações assimétricas de poder, interessando-se pelas estratégias cotidianas de resistência. Ainda de acordo com Levi:

\section{GANPHLAC}


[...] nos intervalos entre sistemas normativos estáveis ou em formação, os grupos e as pessoas atuam com uma própria estratégia significativa capaz de deixar marcas duradouras na realidade política que, embora não sejam suficientes para impedir as formas de dominação, conseguem condicioná-las e modificá-las. (LEVI, 2000, p. 45)

No caso argentino, mesmo diante da atuação oficial do Estado e do sentido normatizador representado pelo próprio inquérito (com suas instruções, categorias e, por conseguinte, escolhas e exclusões), também se tornaram latentes os meandros pelos quais muitos dos mediadores puderem transitar, ora dialogando, ora se afastando dos sentidos originalmente propostos pelos idealizadores da Encuesta.

Além disso, as distorções provocadas pelos métodos de coleta das manifestações folclóricas também têm se colocado como um desafio para os historiadores que utilizam fontes relacionadas à cultura popular. Ginzburg, por exemplo, reconheceu que os documentos preservados são resultados da apreensão da oralidade pelos processos da escrita, cuja autoria é mediada "por indivíduos, uns mais outros menos, ligados à cultura dominante" (GINZBURG, 2006, p. 13), e provêm "quase todos de 'arquivos da repressão"” (idem, p. 21). Igualmente, é necessário demarcar as dinâmicas próprias da cultura popular, que não é estanque nem alheia às transformações sociais, como argumentavam os estudiosos do folclore desde o século XIX. Assim, nos limites das relações de poder e das possibilidades de recepção e mediação, os docentes não foram apenas intermediários, mas participaram ativamente do inquérito, embora muitas vezes demonstrassem afinidades com os discursos disseminados pelo Estado-nacional.

Outra perspectiva fundamental presente em Giovani Levi é a "modulação local da grande história", ou seja, a ideia de que pequenos assuntos do cotidiano "permitem reconstruir um grande jogo social e político" (REVEL apud LEVI, 2000, p. 25-26). Dessa maneira, o contexto histórico do Río Negro e os fragmentos biográficos do professor Augusto Valle e dos personagens entrevistados e/ou mencionados em seus registros devem ser entendidos à luz de um projeto de nação que possibilitou a realização do próprio inquérito. Afinal, como afirmou Jacques Revel:

O significado histórico e social do Estado não se situa unicamente no nível macro, tampouco somente no nível micro. Situa-se em todos os níveis em que pode ser identificada a implementação do processo estatizante. Cada um propõe, para o Estado, uma imagem diferente, e esta não se superpõe às imagens que podem ser constituídas em outros níveis. Nesse sentido, fazer

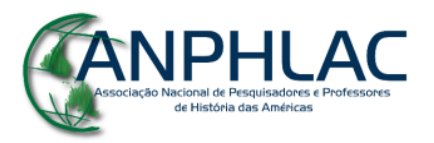

Revista Eletrônica da ANPHLAC, ISSN 1679-1061, №. 24, p. 72-100, Jan./Jun., 2018.

http://revista.anphlac.org.br 
uso de escalas de observação significa levar em consideração formas de descontinuidade presentes no mundo social efetivo. Toda realidade histórica maior, como é o caso do Estado, assume com certeza sua forma e seu sentido numa pluralidade de mundos sociais. (REVEL, 2010, p. 443)

\section{Os registros do professor Augusto Valle: escrita de si e escrita dos outros}

Augusto Valle era professor do terceiro nível primário da Escola Nacional n. ${ }^{\circ} 25$ de Lamarque, localidade situada na ilha Choele Choel, no coração do rio Negro. A ilha foi definitivamente ocupada pelo Estado-nacional argentino em 1879, durante a Conquista do Deserto e o avanço sobre os territórios indígenas. Em 1899, um ano antes da fundação da cidade de Lamarque como colônia agrícola, foi inaugurada a primeira estação de trem da região, cuja economia então se baseava na pecuária bovina e, posteriormente, na agricultura, apesar do clima seco (FLORIA; NICOLETTI, 2001).

Alguns vestígios sobre a história da Escola n. ${ }^{\circ} 25$ corroboram a realidade de distanciamento que caracterizava a relação entre os Territórios Nacionais e as políticas públicas do Estado, especialmente na educação. A iniciativa de construção do estabelecimento partiu de Juan Pedranti, antigo morador da região, em virtude da inexistência de escolas nas proximidades. Primeiramente, ele se dirigiu a um senador em Buenos Aires, em busca de auxílio. Em resposta, o Conselho Nacional de Educação condicionou sua construção à participação da população local na subvenção da empreitada, sob o pretexto de que o investimento não se justificava em virtude da baixa densidade demográfica da ilha. Por conta disso, Pedranti doou o terreno e arcou com os custos da obra. O prédio foi inaugurado em 1909, durante a gestão de Ramos Mejía à frente do CNE (DIÁRIO DO RÍO NEGRO, 2009).

Os primeiros registros do professor Augusto Valle para a Encuesta del Folklore de 1921 tiveram como fontes os relatos de duas testemunhas. A primeira delas, Francisco Giuliani, tinha 33 anos à época do inquérito. Apesar dos dados anotados pelo docente limitarem-se ao nome e à idade desse depoente, encontraremos um Francisco Giuliani entre os integrantes da Comissão de Fomento de Lamarque na década de 1930 (KOPP, 2012), hipótese que indica sua futura importância local. Sobre o segundo entrevistado, Feliciano Cardoso, o professor forneceu informações mais detalhadas: tratava-se de um agente policial de 66 anos que serviu, por mais de duas décadas, no $2^{\circ}$ regimento da cavalaria, participando das Campanhas do Deserto. Assim, sua

\section{GANPHLAC}

Revista Eletrônica da ANPHLAC, ISSN 1679-1061, №. 24, p. 72-100, Jan./Jun., 2018.

http://revista.anphlac.org.br 
permanência em Lamarque pode ter ocorrido em virtude da oferta de terras públicas feita pelo governo como pagamento aos militares que integraram as expedições militares contra os nativos (GARCÍA; TEOBALDO, 1993, p. 348).

Além desses testemunhos, Valle recorreu frequentemente às suas memórias, que nos registros compreendem um intervalo entre 1902 e 1921 e permitem reconstituir parte de sua trajetória de vida. Algumas delas aparecem relacionadas a uma suposta autobiografia, indicada nos documentos pelo título Mis recuerdos, ainda que não tenha sido localizada qualquer publicação nesse sentido em nenhum indexador bibliográfico. $\mathrm{O}$ sequenciamento e numerações dados às folhas parecem não acompanhar, estritamente, a ordem de coleta dos depoimentos e de inclusão das anotações. Em determinada passagem, por exemplo, o professor citou que determinado fato já havia sido "indicado anteriormente", mas a informação aparece registrada apenas oito fólios depois. Há, ainda, ligeira diferença na caligrafia. No entanto, em linhas gerais, ele procurou adotar algumas divisões da classificação proposta pelo Conselho.

Com o auxílio de suas recordações pessoais, o professor mencionou o tempo em que fizera parte de um grupo de estudantes, formado por jovens de Viedma e de Carmen de Patagones, cidades separadas pelas águas do rio Negro. A primeira localizava-se no então Território Nacional e a segunda, na vizinha província de Buenos Aires. O grupo habitualmente viajava de carruagem à Capital Federal ou a Bahía Blanca para estudos e exames acadêmicos. Ao relatar uma dessas viagens, feita no ano de 1906, Valle definiu a região como uma "terra maldita", um "áspero deserto" com pequenos povoados e estâncias que eram verdadeiros "oásis" na paisagem triste.

Essa paisagem, descrita por ele de forma telúrica, a partir de características geográficas vistas como negativas, teria sido transformada pela ferrovia, que anunciou "a cultura e o progresso". Seu entusiasmo pelo trem, símbolo da civilização, contrastava com as viagens guiadas por cavalos, que levantavam poeira nas estradas de terra. No relato, despontam as necessidades educacionais representadas pelos deslocamentos a cidades maiores, que evidenciavam a precariedade das políticas de Estado em relação aos Territórios Nacionais. No entanto, a ideia da redenção do deserto atrasado pelo progresso tecnológico acercava o pensamento do professor ao dicotômico discurso civilizatório perseguido desde os governos liberais, legitimadores do mesmo projeto de

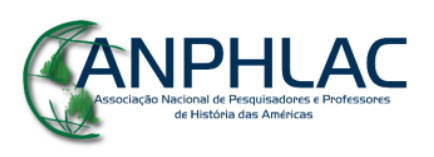

Revista Eletrônica da ANPHLAC, ISSN 1679-1061, №. 24, p. 72-100, Jan./Jun., 2018.

http://revista.anphlac.org.br 
nação que avançava em direção ao Río Negro, em consonância com a retórica do próprio CNE.

Paradoxalmente, boa parte dos materiais compilados por Augusto Valle, inclusive os originados de suas memórias, mantém relação com os indígenas, sobretudo os tehuelches, justamente sobre os quais recaíram as primeiras tentativas de dominação dos governos centrais na região. Historicamente, esse grupo participou de intensos processos interétnicos que incluíram o comércio e a guerra. Como resultado dessas interações, por exemplo, está o próprio termo tehuelche, "gente feroz", que teve origem no idioma dos índios mapuches (SARASOLA, 1992, p. 64). Os tehuelches autodenominavam-se chon - "homens" (FLORIA; NICOLETTI, 2001, p. 22).

Segundo o paleontólogo Rodolfo Casamiquela (CASAMIQUELA, 1969), a área próxima ao rio Negro era habitada pelos tehuelches setentrionais que haviam se mesclado a distintos grupos tehuelches e de outras denominações. Esse contexto geográfico-cultural conformava o chamado complexo tehuelche, caracterizado por formas de vida e língua comuns, apesar das variantes dialetais (SARASOLA, 1992, p. 64-65). Por meio do contato com espanhóis e criollos, os tehuelches incorporaram cavalos, boleadeiras e outros artefatos materiais e hábitos culturais. Também realizavam trocas comerciais, em especial envolvendo o gado, com o que negociavam aquilo que não produziam (FLORIA; NICOLETTI, 2001, p. 24).

As interações com o mundo hispanocriollo e com outros grupos indígenas produziram transformações culturais importantes nas áreas limítrofes ao rio Negro. Em primeiro lugar, o chamado processo de tehuelchización significou a expansão dos tehuelches ao longo dos séculos XVII e XVIII. Paralelamente, a mapuchización (ou araucanização) caracterizou-se pela interação entre os mapuches chilenos e os indígenas argentinos, combinando-se a movimentos migratórios (SARASOLA, 1992; FLORIA; NICOLETTI, 2001). Em muitos documentos coletados no Río Negro, elementos culturais atribuídos originalmente a um desses grupos acabaram por se confundir nos registros dos professores. Por outro lado, a persistência dos indígenas nas páginas colhidas pelo inquérito corrobora sua capacidade de resistência e de rearticulação, apesar das tentativas de invisibilização a que eram, e ainda são, constantemente submetidos.

\section{GANPHLAC}

Revista Eletrônica da ANPHLAC, ISSN 1679-1061, №. 24, p. 72-100, Jan./Jun., 2018.

http://revista.anphlac.org.br 
A figura do Gualicho, entidade sobrenatural frequentemente documentada pela Encuesta del Folklore, foi definida pelo professor Augusto Valle como um "costume ridículo e tradicional". No entanto, ao mesmo tempo, também apareceu descrita por ele como um ser supremo, um dos criadores do mundo e do bem e do mal. O docente explicou que os tehuelches, sendo nômades, cultuavam objetos naturais ao invés de templos, atribuindo-lhes poderes. Entre eles, estavam as chamadas árvores do Gualicho, uma das quais ele conheceu durante suas viagens de juventude.

Em uma parada para o descanso das montarias, os viajantes repousaram próximos a um solitário algarrobo, espécie de árvore comum na região. Em seus galhos estavam pendurados trapos de roupa e bens de pouco valor. Curiosos, foram informados pelo cocheiro que a árvore era venerada pelos índios. Eles prendiam os objetos quando passavam, a fim de espantar o Gualicho, ou "espírito do mal". O costume também era seguido por muitos camponeses, informou o condutor. Os jovens resolveram pôr a crença à prova: penduraram alguns lenços nos galhos, a fim de ver se permaneceriam intocados quando voltassem ou se seriam subtraídos. No regresso, comprovando que os panos estavam preservados, o que contrariou a suspeita prévia de que seriam roubados pelos indígenas, finalmente acreditaram que a árvore era respeitada por todos. Para Valle, aquilo se tratava de uma "ridícula superstição, cuja origem estava em tempos remotos, baseada na crença religiosa das tribos tehuelches, confundidas com os araucanos em sua fuga da civilização”. Por um lado, essa passagem revela a posição de alteridade na qual se enxergava o professor, ao estigmatizar os índios e os criollos que partilhavam de suas crenças. Por outro, demonstra o dinamismo das práticas e contatos cotidianos da fronteira, dos quais os próprios estudantes não escaparam.

Outros relatos de viagem mencionaram o Gualicho. Segundo Lucio Victorio Mansilla, o espírito era tido como a causa de todo o mal pelos ranqueles, incluindo guerras e enfermidades, e poderia possuir seres animados e inanimados (MANSILLA, 1989, p. 286). Charles Darwin, no célebre diário redigido a bordo do navio Beagle, registrou a veneração à Árvore do Gualicho e as oferendas realizadas pelos índios, as quais eram roubadas pelos gauchos (DARWIN, 2015, E-book), o que inverte o julgamento feito pelo professor Valle em suas memórias. O cientista britânico relatou também que a entidade era vista como a razão de todos os malefícios que acometiam os

\section{GANPHLAC}

Revista Eletrônica da ANPHLAC, ISSN 1679-1061, №. 24, p. 72-100, Jan./Jun., 2018.

http://revista.anphlac.org.br 
tehuelches, que lhe ofertavam sacrifícios e prendas, de modo a aplacar os danos que lhes poderiam ser causados (ROJAS, 2012, p. 27).

$\mathrm{Na}$ documentação de Augusto Valle, ainda há menções ao Gualicho como superstições sobre jogos e caça: os meninos tehuelches, brincando de gude, sopravam e gritavam seu nome para expulsá-lo das bolinhas e evitar a derrota; nas caçadas, em caso de insucesso, o estilingue, arco ou instrumento utilizado era jogado no chão, para conjurar e afugentar o Gualicho. A entidade foi igualmente citada pelos entrevistados do professor. Francisco Giuliani narrou os choros e gritos das mulheres indígenas durante o velório de um chefe. Ao mesmo tempo, os homens davam golpes de faca e boleadeiras no ar, nas paredes e na cama do falecido, a fim de expulsar o Gualicho, possuidor da casa e causador daquela morte. A moradia era abandonada após o enterro.

Também Feliciano Cardoso falou sobre a existência de um poço profundo, venerado pelos índios e conhecido como o Poço do Gualicho. Ele ficava nas imediações de Junín de los Andes, em Neuquén, revelando a abrangência das práticas tehuelches e o deslocamento das narrativas da Encuesta para outros espaços geográficos. Cardoso ainda relatou o significado do Gualicho nos casamentos e nascimentos. Os tehuelches davam voltas na casa do recém-nascido ou dos recém-casados, batendo instrumentos e gritando, a fim de expulsar o espírito mau. Enquanto isso, cantavam para atrair o espírito bom e a sorte para o bebê ou os noivos. Em seguida, eram realizados bailes e festejos que, segundo ele, contavam com bebida e muitas vezes terminavam em briga.

A menção ao álcool, sobretudo associado aos indígenas, foi recorrente em materiais do inquérito. Desde a colonização, a embriaguez fazia parte dos estereótipos de negativação do nativo (FLORIA, 2001, p. 32). Componente essencial de rituais e cerimônias religiosas, o álcool converteu-se em elemento de controle pelos espanhóis e, posteriormente, pelos governos nacionais argentinos (MASES, 2002, p. 32), cujo comércio era manipulado para a criação de laços de dependência. Pela América Latina, os emblemas de bêbado e preguiçoso, entre outros, ainda servem para detratar os indígenas: “o olhar de comiseração que vê o índio como um ‘bêbado, fraco e ladrão' só conduz à dominação e ao extermínio" (BENGOA, 2000, p. 8). Outra referência ao álcool, combinada ao sacrifício de animais, apareceu na descrição de Augusto Valle do camaruco, durante cerimônia dedicada a pedir chuva. Os camarucos, originalmente

\section{GANPHLAC}


mapuches, eram os maiores rituais coletivos de expressão religiosa e social, dedicados a rogativas (DUPEY; PODUJE, s/d, p. 97).

Ainda sobre o casamento, Feliciano Cardoso apontou a ocorrência da poligamia. A quantidade de mulheres desposadas, segundo a testemunha, variava de acordo com a posição social do homem no grupo: para os caciques, os mais importantes, chegava a até cinco esposas; para os capitanejos, chefes menores, a três. $\mathrm{O}$ agente de polícia descreveu, também, vestimentas e adereços utilizados pelos indígenas, como camisas curtas e largas, chapéus, botas de couro, faixas ou cocares na cabeça, penachos, pinturas corporais e o chiripá, tipo de poncho tradicional. A descrição parece uma combinação da indumentária dos índios com a dos gauchos. O chiripá, inclusive, foi associado à barbárie por Domingo Faustino Sarmiento, como símbolo de atraso e barreira à civilização (SARMIENTO apud PALERMO, 2015, p. 175).

Outras práticas tehuelches relatadas por Feliciano Cardoso foram classificadas pelo professor Valle como curandeirismo. Segundo o entrevistado, eram receitas muito úteis nas batalhas, diante da escassez de recursos que caracterizava a região. Com os índios, o antigo soldado aprendeu tratamentos naturais para a cura de ferimentos e doenças. Paradoxalmente, muitos desses conhecimentos foram possivelmente utilizados por ele durante as Campanhas do Deserto contra os próprios indígenas. Augusto Valle observou que, no momento do inquérito, alguns dos ingredientes estavam "à venda em farmácias" ou eram usados pelos "civilizados". Além disso, o professor registrou que outras receitas medicinais relatadas pela testemunha continuavam comuns entre os "camponeses curandeiros". Nesse sentido, contraditoriamente, Augusto Valle diferenciou as farmácias - entendidas como loci de civilização - das práticas populares - com suas superstições e curandeirismos -, mesmo após reconhecer a assimilação de elementos de uma por parte da outra.

Outro costume exógeno ao Río Negro foi relatado pelo mesmo depoente. Na Cordilheira dos Andes, Feliciano havia presenciado os índios utilizarem uma estreita fenda, localizada no cume de uma montanha, a fim de obter presságios. Ao atravessarem-na a cavalo, caso o animal não tocasse em suas extremidades, era sinal de sorte para malonear (atacar de surpresa, geralmente vilas e propriedades rurais criollas); caso contrário, era mau agouro e desistiam de empreender o ataque. A importância cotidiana dos equinos também apareceu em outros registros colhidos de Feliciano

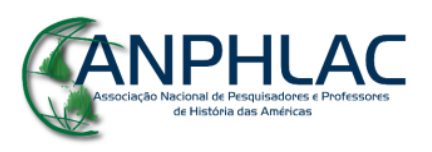

Revista Eletrônica da ANPHLAC, ISSN 1679-1061, №. 24, p. 72-100, Jan./Jun., 2018.

http://revista.anphlac.org.br 
Cardoso. Segundo ele, nos enterros, o cadáver do homem tehuelche era sepultado com todos os seus bens, incluindo o animal preferido.

Não por acaso, o cavalo representou uma transformação cultural significativa entre os tehuelches setentrionais (SARASOLA, 1992, p. 25-27). A partir do século XVI, quando expedições espanholas fracassadas resultaram no abandono de criações, os equinos passaram a se reproduzir na vida selvagem. Foram então domesticados pelos índios e incorporados às suas práticas materiais e simbólicas. Com isso, sua mobilidade foi facilitada, ampliando-se as possibilidades de deslocamento territorial e suas consequências para a organização social. Igualmente, atividades estratégicas, como a caça e a guerra, foram aperfeiçoadas. Os hábitos alimentares também passaram a incluir o consumo da carne de cavalo e égua e os animais começaram a ocupar destacada importância ritualística, como nas cerimônias de sepultamento de seus donos e no oferecimento de sacrifícios.

Na sequência de sua contribuição, Feliciano relatou a lembrança de um fato ocorrido em 1878 ou 1879 e classificado pelo professor Valle como "narração histórica", categoria inexistente no esquema original da Encuesta. Dizia respeito à prisão de um cacique de nome Topayo, "cruel e traidor, como os tehuelches na guerra". Segundo o relato, após ser capturado, o líder indígena simulara submissão aos criollos, para pouco depois rebelar-se, fugindo com milhares de índios e centenas de cavalos. Perseguido a mando do capitão Baigorria, figura célebre das Campanhas do Deserto, Topayo foi novamente preso e condenado à morte. No momento em que seria cumprida sua ordem de fuzilamento, o indígena foi degolado de surpresa por um soldado, gesto considerado "humanitário" pela testemunha. Essa narração ilustra a inversão presente nos discursos de alteridade de regiões de fronteira: enquanto o índio era visto como cruel e traidor (o que legitimava seu extermínio), a memória social sobre o conquistador revestia-o de virtude e dignidade, a despeito da desleal execução do cacique.

A documentação de Augusto Valle prosseguiu com a lembrança da apresentação de uma banda escolar privada de Viedma, ocorrida no porto de Carmen de Patagones em 1902, que executava marchas militares em homenagem ao inspetor das escolas salesianas. Segundo ele, metade dos músicos era indígena, característica justificada pela constatação de que "os tehuelches possuíam inclinação natural para a música". O

\section{GANPHLAC}

Revista Eletrônica da ANPHLAC, ISSN 1679-1061, №. 24, p. 72-100, Jan./Jun., 2018.

http://revista.anphlac.org.br 
próprio professor informou ter lecionado essa disciplina para meninos, contando com alunos indígenas em sua turma que eram hábeis cantores e músicos.

Essa passagem corrobora a relevância dos salesianos para a educação do Río Negro. Em virtude da debilidade das políticas levadas a cabo pelo Conselho Nacional de Educação, a congregação mantinha grande ascendência sobre a Patagônia desde o final do século XIX, aspecto que perdurou por décadas (FLORIA; NICOLETTI, 2001, p. 117-122). Aliás, entre os propósitos de Dom Bosco, fundador dessa ordem italiana em 1859, estava a "conversão e civilização dos indígenas patagônicos" (idem, p 118). Por conseguinte, a escola era assumida como instrumento de incorporação cultural e doutrinação, valorizada não apenas pelo Estado, mas também por instituições centralizadoras como a Igreja.

Além disso, Augusto Valle pode ter sido um aluno salesiano, hipótese que indicaria uma origem humilde de colono, outro público prioritariamente atendido pelas obras assistenciais da congregação no Río Negro (GARCÍA; TEOBALDO, 1993, p. 355). Isso porque relatou ter sido colega de classe de Ceferino Namuncurá, a quem atribuiu "fino ouvido musical e uma voz agradável". Ceferino é considerado o símbolo do índio convertido ao cristianismo e, por conseguinte, das tentativas de dominação dos nativos. Era filho de Manuel Namuncurá, importante cacique mapuche. Aluno salesiano (primeiro em Buenos Aires, depois em Viedma) e aspirante ao sacerdócio, faleceu de tuberculose aos 18 anos em Roma, pouco depois de ser recebido pelo Papa Pio X. Após décadas de forte devoção popular na Argentina, foi beatificado em 2007. Atualmente, seu processo de canonização prossegue no Vaticano.

Reconhecido como o "santinho criollo" ou o "mapuche santo", a elevação de Ceferino Namuncurá à santidade conformou a violência simbólica da Conquista do Deserto (NICOLETTI, 2009). Desde a década de 1910, circulavam relatos nesse sentido. Ainda assim, o professor Augusto Valle não fez, em seus registros pessoais, qualquer alusão a esse relevante pormenor, sendo impossível afirmar se essa famigerada característica, caso conhecida por ele, tenha motivado a inclusão de Ceferino em suas memórias. Curiosamente, Manuel Gálvez, um dos principais expoentes da Geração do Centenário e de seu pensamento nacionalista, foi autor de uma das idealizadas biografias do "santito de la toldería", publicada na década de 1940 (GÁLVEZ, 1947).

\section{GANPHLAC}


O docente prosseguiu com apontamentos geográficos, relatando a ocasião em que, como estudante, viajava a bordo de um navio a vapor, o qual teve dificuldades para adentrar no leito do rio Negro. Isso por conta de um fenômeno recorrente, o da barra picada, ou seja, de um banco de areia que impossibilitava os barcos de atracarem. Desde a colonização, a navegabilidade daquele rio era considerada estratégica para a ocupação da região, atributo que se manteria importante mesmo após a chegada da linha férrea.

Encerrando sua compilação para o inquérito, Augusto Valle enumerou uma série de adivinhações, coletadas entre 1914 e 1921. Anotou que elas eram populares em Lamarque e General Roca, o que denota seus deslocamentos e a possível vivência nessa outra cidade rionegrina, distante 200 quilômetros da Escola Nacional n. ${ }^{\circ}$ 25. Os temas das charadas relacionavam-se ao cotidiano do campo e suas soluções incluíam nomes de maquinários agrícolas, espécies vegetais e animais, fenômenos da natureza e objetos comuns do dia a dia, por exemplo: “em um monte muito próximo há um padre franciscano, tem dentes e não come, tem barba e não é homem (o milho)".

As adivinhações, como partes de um conhecimento iminentemente popular, comuns em várias culturas e associadas ao folclore desde o século XIX, vêm sendo recentemente estudadas também pela linguística graças a seu potencial pedagógico e como gênero de comunicação. Enigmas a serem desvendados a partir de uma pergunta curta, que já fornece as pistas para sua resposta, elas dependem da interação entre "aspectos linguísticos, saberes e crenças, pois o comportamento verbal do indivíduo e a estrutura do código linguístico subjacente ao comportamento estão abertos a influências sociais e culturais" (DIONISIO, 1999, p. 608). Assim, é natural que as charadas se originem de vestígios do cotidiano: condicionadas à memória social e ao conhecimento coletivo, elas permitem às pessoas que encontrem à sua volta a chave para a resolução do problema.

\section{Considerações finais}

Os registros levantados por Augusto Valle são importantes para demonstrar as diversas possibilidades de recepção, elaboração e atuação do professor, enquanto mediador e participante da Encuesta. Valendo-se do olhar de testemunhas que, pela posição social, pareciam gozar de influência local, seus documentos também

\section{CANPHLAC}

Revista Eletrônica da ANPHLAC, ISSN 1679-1061, №. 24, p. 72-100, Jan./Jun., 2018.

http://revista.anphlac.org.br 
incorporaram aspectos pessoais e biográficos que superaram as limitações esquemáticas do inquérito. Esse protagonismo incluiu a citação de suas memórias, as quais tentou acomodar, algumas com facilidade, outras indiretamente, às instruções do Conselho.

À primeira vista, e sobretudo ao tratar dos tehuelches, o docente pareceu aproximar-se dos discursos hegemônicos da oposição entre a civilização e a barbárie, por meio da valorização de alguns símbolos, como a ferrovia, e da depreciação de outros, como o deserto. Essas imagens antagônicas muitas vezes foram utilizadas para os Territórios Nacionais, a fim de anular tensões sociais e contribuir para sua marginalização, e continuavam em voga nas primeiras décadas do século XX (CONSELHO NACIONAL DE EDUCAÇÃO; GALLARDO, 1920, p. 105-120).

Além disso, Valle pareceu assumir a posição de alteridade de um "quase viajante", o que possibilitou registrar de modo mais contundente, ainda que involuntário e perpassado por juízos de valor, dinâmicas assimétricas, sentidos de dominação e formas complexas de interação cultural. Ao mesmo tempo, seus apontamentos não apenas o posicionaram como sujeito integrante daquela realidade histórica, como igualmente esvaziaram, pela riqueza e multiplicidade de seus aportes, a imagem simbólica do deserto que ele pretendeu inicialmente abraçar.

Por outro lado, em documentação levantada pela historiadora Cielo Zaidenwerg para sua tese de doutoramento, existe a menção a uma reprimenda sofrida por um professor de nome Augusto Valle em 1917, feita pelo então diretor da Escola n. ${ }^{\circ} 33$ de Cipolletti, outra cidade rionegrina que também participaria da Encuesta Nacional del Folklore de 1921 (ZAIDENWERG, 2013, p. 243-244). Devido à homonímia, à proximidade entre as escolas e à breve antecedência da data, e diante da debilidade do quadro funcional dos estabelecimentos do Río Negro que possivelmente motivava deslocamentos e transferências constantes, é provável que se trate da mesma pessoa.

O docente foi acusado de ser um "estrangeirizador" ao invés de um “argentinizador", contrariando as orientações pedagógicas do CNE e priorizando temas desvinculados de seu programa patriótico, sendo então instruído a enfocar em suas aulas os temas determinados pelo Conselho. Esse episódio combina-se ao posicionamento crítico e independente que transpareceu em distintas passagens da compilação do professor Augusto Valle de Lamarque, crítico de práticas e características regionais que considerava atrasadas, embora idealizadas como tradições nacionais pelo discurso

\section{GANPHLAC}

Revista Eletrônica da ANPHLAC, ISSN 1679-1061, №. 24, p. 72-100, Jan./Jun., 2018.

http://revista.anphlac.org.br 
nacionalista. Corrobora, principalmente, os argumentos sobre as maneiras encontradas pelos docentes para atuar nos interstícios das normas e do controle do Conselho Nacional de Educação: ostensivo, mas nem por isso ilimitado.

\section{Referências Bibliográficas}

\section{Fontes}

ANAIS DA LEGISLAÇÃO ARGENTINA. Lei de Educação Comum, sancionada em 26 de junho de 1884 e promulgada em 08 de julho de 1884. Disponível em: http://www.bnm.me.gov.ar/giga1/normas/5421.pdf Acesso em: 08 de dezembro de 2017.

CENTRE NATIONAL DE RESSOURCES TEXTUELLE ET LEXICALES. Disponível em: http://www.cnrtl.fr/etymologie/enqu\%C3\%AAte Acesso em: 30 de março de 2018.

CONGRESSO NACIONAL DA ARGENTINA. Lei n. ${ }^{\circ} 215$ de 13 de agosto de 1867.

Lei n. ${ }^{\circ} 4.144$ de 22 de novembro de 1902.

Lei n. ${ }^{\circ} 4.878$ de 17 de outubro de 1905.

CONSELHO NACIONAL DE EDUCAÇÃO. Cincuentenario de la Ley 1420, v. 2, 1938.

CONSELHO NACIONAL DE EDUCAÇÃO; GALLARDO, Ángel. La enseñanza primaria en los territorios nacionales. El Monitor de la Educación Común, año 38, $\mathrm{n}^{\mathrm{o}}$ 569, Buenos Aires, 1920.

CONSELHO NACIONAL DE EDUCAÇÃO; RAMOS, Juan Pedro. Proyecto del vocal del Consejo Nacional de Educación Dr. Juan P. Ramos. In: Folklore Argentino. Buenos Aires: Conselho Nacional de Educação, 1921.

CONSELHO NACIONAL DE EDUCAÇÃO; RAMOS, Juan Pedro; CÓRDOBA, Pablo A. Instrucciones a los maestros para el mejor cumplimiento de la resolución adoptada pelo H. Consejo sobre Folklore Argentino. El Monitor de la Educación Común, Consejo Nacional de Educación, año 39, n 580, Buenos Aires, 30 de abril de 1921.

DIÁRIO RÍO NEGRO. La 25, una escuela centenaria. Diário Río Negro. Río Negro, Sociedade, p. 37, 05 de julho de 2009. Disponível em: http://www1.rionegro.com. ar/diario/2009/07/05/1246759229224.php\# Acesso em: 02 de dezembro de 2017.

KOPP, Juan José. Colonia de la Isla de Choele Choel. Choele-Choel, Fray Luis Beltrán, Lamarque y Pomona. Gobernación del Territorio del Río Negro. Años de 1900 a 1939. Disponível em: http://archive.org/stream/ColoniaDeLaIslaDelChoeleChoel/ColoniaDe LaIslaDelChoeleChoel_djvu.txt Acesso em: 14 de dezembro de 2017.

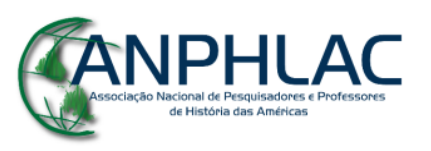

Revista Eletrônica da ANPHLAC, ISSN 1679-1061, №. 24, p. 72-100, Jan./Jun., 2018.

http://revista.anphlac.org.br 
SARMIENTO, Domingo F. Carta de Sarmiento a Bartolomé Mitre, 24 de setembro de 1861. In: PALERMO, Vicente. La alegría y la pasión: Relatos brasileños y argentinos en perspectiva comparada. Madri: Katz, 2015.

SECRETARIA DE AGRICULTURA, INDÚSTRIA E COMÉRCIO. Boletim do Departamento de Imigração e Colonização. São Paulo, nº 5, dezembro de 1950.

VALLE, Augusto; COLECCIÓN DE FOLKLORE DE 1921. Planificación y ejecución de la recolección de materiales de folklore: Consejo Nacional de Educación. Río Negro, rolo $n^{\circ}$ 059, pasta $n^{\circ} 15$. [Microfilmes disponíveis para consulta in loco na Biblioteca Juan Alfonso Carrizo do Instituto Nacional de Antropología y Pensamiento Latinoamericano, Buenos Aires].

\section{Bibliografia}

ALBERDI, Juan B. Bases y puntos de partida para la organización política de la República de Argentina. Fundação Biblioteca Virtual Miguel de Cervantes, 2011.

BEIRED, José Luiz B. Sob o signo da nova ordem - intelectuais autoritários no Brasil e na Argentina. São Paulo: Edições Loyola, 1999.

BENGOA, José. Historia del pueblo mapuche: siglo XIX y XX. Santiago: LOM, 2000.

BETHELL, Leslie (Org.). História da América Latina (volume III) - da Independência a 1870. São Paulo: Editora da Universidade de São Paulo; Brasília: Fundação Alexandre de Gusmão, 2009.

BONI, Valdete; QUARESMA, Silvia J. Aprendendo a entrevistar: como fazer entrevistas em Ciências Sociais. Revista Eletrônica dos Pós-Graduandos em Sociologia Política da UFSC, v. 2, nº 1 (3), janeiro-julho/2005.

BURKE, Peter. Cultura Popular na Idade Moderna: Europa, 1500-1800. São Paulo: Cia. das Letras, 2010.

CANCLINI, Néstor G. Culturas híbridas: estrategias para entrar y salir de la modernidad. Cidade do México: Grijalbo, 1990.

CASAMIQUELA, Rodolfo. Un nuevo panorama etnológico del área pampeana y patagónica adyacente. Santiago: Ediciones del Museo Nacional de Historia Natural, 1969.

CATTARUZZA, Alejandro. Los usos del pasado. La historia y la política argentinas en discusión 1910-1945. Buenos Aires: Sudamericana, 2012, E-book.

DARWIN, Charles. The Voyage of the Beagle. New York: Sheba Blake Publishing, 2015, E-book.

\section{GANPHLAC}

Revista Eletrônica da ANPHLAC, ISSN 1679-1061, №. 24, p. 72-100, Jan./Jun., 2018.

http://revista.anphlac.org.br 
DEVOTO, Fernando J. Imigração europeia e identidade nacional nas imagens das elites argentinas (1850-1914). In: FAUSTO, Boris (Org.). Fazer a América - a imigração em massa para a América Latina. São Paulo: EDUSP, 2000.

DIONISIO, Angela Paiva. A organização textual-interativa das adivinhas. In: MOURA, Denilda (Org.). Os múltiplos usos da língua. Maceió: Edufal, 1999.

DUPEY, Ana María; PODUJE, María Inés. Narrar identidades y memorias sociales: estructura, procesos y contextos de la narrativa folklórica. La Pampa: Departamento de Investigaciones Culturales de la Subsecretaría de Cultura, s/d.

ESPOSITO, Fabio; DI CROCE, Ely. Un archivo del folklore nacional: la Encuesta de Magisterio de 1921. VI Jornadas Internacionales de Filología y Lingüística y Primeras de Crítica Genética "Las lenguas del archivo". La Plata, 2013.

FERREIRA, Leticia. Proyecto de Microfilmación de la Colección de Folklore de 1921. Buenos Aires: Instituto Nacional de Antropología y Pensamiento Latinoamericano, s/d.

FLORIA, Pedro N. El salvaje y su tratamiento en el discurso político argentino sobre la frontera sur. Revista de Indias, vol. 61, n. 222, 2001, p. 345-376.

FLORIA, Pedro N.; NICOLETTI, María A. Río Negro, mil voces en una historia. Neuquén: Manuscritos Libros, 2001.

FUENTE, Ariel de la. Children of Facundo: Caudillo and Gaucho Insurgency during the Argentine State-Formation Process (La Rioja, 1853-1870). Durham; Londres: Duke University Press, 2001.

GÁLVEZ, Manuel. El santito de la toldería: la vida perfecta de Ceferino Namuncurá. Buenos Aires: Poblet, 1947.

GARCÍA, A. Beatriz; TEOBALDO, Mirta. Estado y sociedad civil en la conformación y desarrollo del sistema educativo en el territorio nacional de Río Negro (1884-1945). In: PUIGGRÓS, Adriana (Org.). La Educación en las Provincias y Territorios Nacionales (1885-1945). Buenos Aires: Galerna, 1993.

GINZBURG, Carlo. O queijo e os vermes - o cotidiano e as ideias de um moleiro perseguido pela inquisição. São Paulo: Cia. das Letras, 2006.

GOMES, Angela de Castro (Org.). Escrita de si, escrita da História. Rio de Janeiro: Editora FGV, 2004.

LEVI, Giovanni. A herança imaterial: a trajetória de um exorcista no Piemonte do século XVII. Rio de Janeiro: Civilização Brasileira, 2000.

LIMA, Marinús Pires de. Inquérito Sociológico: Problemas de Metodologia. Preparação de Inquéritos, Recolha de Dados, Tratamento da Informação, Métodos e Técnicas, Sondagens e Entrevistas. Lisboa: Editorial Presença, 2000.

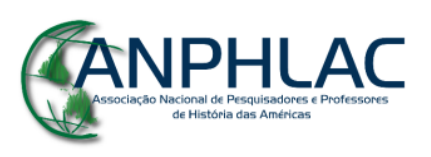

Revista Eletrônica da ANPHLAC, ISSN 1679-1061, №. 24, p. 72-100, Jan./Jun., 2018.

http://revista.anphlac.org.br 
MANSILLA, Lucio Victorio. Una excursión a los indios ranqueles. Buenos Aires: Emecé, 1989.

MASES, Enrique Hugo. Estado y cuestión indígena - El destino final de los indios sometidos en el sur del territorio (1878-1910). Buenos Aires: Prometeo Libros, 2002.

MARTIN, Francisco Alvira. La encuesta: una perspectiva general metodológica. Madri: Centro de Investigaciones Sociológicas, 2011.

MIGLIOZZI, María T. C. Luis Gerónimo Lucero: su aporte a la investigación folclórica de San Luis. Disponível em: http://biblioteca.sanluis.gov.ar/Publicaciones/LUIS\% 20GERONIMO\%20LUCERO-\%20SEGUNDA\%20PARTE.pdf Acesso em: 01 de abril de 2018 .

MOLDES, Beatriz; ENTRAIGAS, Jorge. La población del Territorio Nacional del Río Negro. Un aporte al conocimiento de sus principales características demográficas (1884-1955). IX Jornadas Argentinas de Estudios de Población. Asociación de Estudios de Población de la Argentina, Córdoba, 2007. Disponível em: https://www.aacademi ca.org/000-028/79.pdf Acesso em: 10 de dezembro de 2017.

NÉIA, Vitor Hugo S. O folclore e a escrita da História: a cultura popular como fonte. Resgate: Revista Interdisciplinar de Cultura, v. 25, $\mathrm{n}^{\circ}$ 1, p. 203-226.

NICOLETTI, María A. El camino a los altares: Ceferino Namuncurá y la construcción de la santidad. Revista TEFROS, v. 7, n ${ }^{\circ} 1-2$, dezembro de 2009.

OSZLAK, Oscar. Reflexiones sobre la formación del estado y la construcción de la sociedad argentina. Desarrollo Económico Revista de Ciencias Sociales, vol. XXI, 1982, Janeiro-Março: Buenos Aires.

PINEAU, Pablo (Org.). A cien años de la Ley Láinez. Buenos Aires: Ministerio de Educación, Ciencia y Tecnología, 2007.

PUIGGRÓS, Adriana (Org.). Historia de la educación argentina. Sociedad civil y estado en los orígenes del sistema educativo argentino. Buenos Aires: Editorial Galerna, 1991.

RAMOS MEJÍA, José María. La Escuela Argentina en el Centenario. Buenos Aires: Conselho Nacional de Educação, 1909.

REVEL, Jacques. Prefácio. In: LEVI, Giovanni. A herança imaterial: a trajetória de um exorcista no Piemonte do século XVII. Rio de Janeiro: Civilização Brasileira, 2000.

REVEL, Jacques. Micro-história, macro-história: o que as variações de escala ajudam a pensar em um mundo globalizado. Revista Brasileira de Educação, v. 15, $\mathrm{n}^{\mathrm{o}}$ 45, set./dez. 2010, p. 434-444.

ROJAS, Oscar A. Memorial de la Patagonia. Santiago: RIL Editores, 2012.

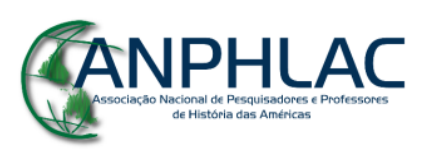

Revista Eletrônica da ANPHLAC, ISSN 1679-1061, №. 24, p. 72-100, Jan./Jun., 2018.

http://revista.anphlac.org.br 
ROMERO, Luis Alberto. Breve História Contemporânea da Argentina. Buenos Aires: Fondo de Cultura Económica, 2012, E-book.

SARASOLA, Carlos. Nuestros paisanos los indios. Buenos Aires: Emecé, 1992.

SARMIENTO, Domingo. Facundo, ou civilização e barbárie. São Paulo: Cosac Naify, 2010.

SOARES, Gabriela Pellegrino. A Semear horizontes. Leituras literárias na formação da infância, Argentina e Brasil (1915-1954). Tese de Doutorado em História Social. São Paulo: Universidade de São Paulo, 2002.

SOARES, Gabriela Pellegrino. Monteiro Lobato, Juan P. Ramos e o papel dos inquéritos folclóricos na formação cultural e política da nação. Varia Historia, Belo Horizonte, v. 31, $\mathrm{n}^{\mathrm{o}} 56,2015$, p. 423-448.

ZAIDENWERG, Cielo. La 'argentinización' de los Territorios Nacionales a través de la educación formal e informal: Estudio de caso Río Negro (1908-1930). Tese de Doutorado em História da Universidade de Barcelona. Universitat de Barcelona: Barcelona, 2013.

ZAIDENWERG, Cielo. Amar, honrar y servir la Patria. Las escuelas del Territorio Rionegrino y su aporte a la obra argentinizadora en el Sur (1908-1930). Páginas Revista Digital de la Escuela de Historia, año 5, nº 9, Rosário, 2013, p. 61-89.

ZAIDENWERG, Cielo. Un proyecto 'argentinizador'. Educación y efemérides en la región patagónica y rionegrina. História Unisinos, v. 17, $\mathrm{n}^{\mathrm{o}} 3$, setembro/dezembro de 2013, p. 237-247.

\section{GANPHLAC}

